\title{
Weed Spectrum in Durum Wheat under Different Soil Tillage and Fertilizer Application in Mediterranean Environment
}

\author{
Verdiana Petroselli ${ }^{1}$, Emanuele Radicetti ${ }^{2, *} \mathbb{B}$, Alireza Safahani Langeroodi ${ }^{3}{ }^{(\mathbb{O}}$, Mohamed Allam $^{1}$ \\ and Roberto Mancinelli ${ }^{1}$ (D) \\ 1 Department of Agricultural and Forestry Sciences (DAFNE), University of Tuscia, Via San Camillo de Lellis, \\ snc, 01100 Viterbo, Italy; verdiana.petroselli@unitus.it (V.P.); mohamed.allam@studenti.unitus.it (M.A.); \\ mancinel@unitus.it (R.M.) \\ 2 Department of Chemical, Pharmaceutical and Agricultural Sciences (DOCPAS), University of Ferrara, Via \\ Luigi Borsari, 46, 44121 Ferrara, Italy \\ 3 Department of Agronomy, Payane Noor University, Tehran 845683111, Iran; safahani.ali@gmail.com \\ * Correspondence: emanuele.radicetti@unife.it
}

Citation: Petroselli, V.; Radicetti, E.; Langeroodi, A.S.; Allam, M.;

Mancinelli, R. Weed Spectrum in Durum Wheat under Different Soil Tillage and Fertilizer Application in Mediterranean Environment. Sustainability 2021, 13, 7307. https://doi.org/10.3390/su13137307

Academic Editor: Sean Clark

Received: 1 June 2021

Accepted: 28 June 2021

Published: 30 June 2021

Publisher's Note: MDPI stays neutral with regard to jurisdictional claims in published maps and institutional affiliations.

Copyright: () 2021 by the authors. Licensee MDPI, Basel, Switzerland. This article is an open access article distributed under the terms and conditions of the Creative Commons Attribution (CC BY) license (https:// creativecommons.org/licenses/by/ $4.0 /)$.

\begin{abstract}
Agricultural intensification may cause significant changes in weed density due to high weed competitiveness. Therefore, sustainable practices are to be designed to get maximum benefits of plant biodiversity in the agro-ecosystems. Field experiments were conducted in 2013/2014 and 2014/2015 to evaluate the impact of fertilizer source and soil tillage on weed spectrum in durum wheat (Triticum durum Desf.). Treatments in this study were: (i) two fertilizer sources (mineral fertilizer (MIN) and municipal organic waste (MOW)), and (ii) three tillage regimes (plowing (Plo), subsoiling (Sub) and spading (SM)). A randomized complete block design with three replications was adopted. Data on weed density and biomass were collected at the wheat tillering stage. Weed density was higher in MOW than MIN (53.8 vs. 44.0 plants. $\mathrm{m}^{-2}$ ), especially in 2014/2015, while $\mathrm{S}$ was the highest among tillage regimes $\left(58.2\right.$ plants $\left.\mathrm{m}^{-2}\right)$. Annual and monocots species were always the highest in subsoiling ( 43.5 and 10.1 plants $\cdot \mathrm{m}^{-2}$ ). The density of perennial and dicots species was higher in MOW compared with MIN plots, regardless of soil tillage management. Weed community, in terms of weed species composition, varied between the two fertilizer sources, while among soil tillage regimes, it only differed between plowing and subsoiling. Based on the analysis of weed community composition, annual dicot species were mainly associated with plowing, while monocots tended to be associated with MIN fertilizer. Spading tillage may be a useful strategy for managing weed diversity under organic fertilization, where mineral soil nitrogen availability was limited. Conversely, the spading machine produced lower grain yields than plowing with mineral fertilizer application.
\end{abstract}

Keywords: sustainable crop management; biodiversity; weed association; weed community composition; crop yield

\section{Introduction}

Conventional agriculture, based on intensive soil tillage and excessive mineral fertilizer applications, aims only to maximize crop yield. These practices are considered unsustainable because they weaken the resilience of agro-ecosystems and thus cause a considerable loss of the structural integrity of the system, in terms of reduced capacity to provide a wide range of ecosystem services, not only for food production but also linked to other such as provisioning, regulating, and supporting services that contribute to maintaining the agro-ecosystems as sustainable [1]. However, the soil tillage practice offers several advantages for crop cultivation, mostly through increased aeration and softness. On the other hand, it is also one of the main causes of soil compaction, especially when using heavy machinery, such as plowing vehicles [2]. In addition, the use of such machinery requires more fossil fuels and causes more greenhouse gas emissions [3]. Moreover, the 
use of moldboard plow tends to bury the organic matter (SOM) in the anoxic deep layer of soil instead of allowing it to be processed in the active zone of soil micro-fauna and micro-organisms [4]. Jaskulska et al. [4] highlight the need to limit the unfavorable effects of conventional agriculture on the environment, replacing it with alternative approaches to crop cultivation, such as conservation agriculture.

Conservation agricultural practices mainly based on minimum disturbance of the soil (minimum tillage or no tillage) and the diversification of plant species improve biodiversity and the natural biological processes and contribute to greater water and nutrient use efficiency, supporting plant production [5]. Moreover, conservation tillage practices promote favorable changes in soil properties, preserve soil moisture, especially during the precipitation deficit, and increase the content of SOM in the $0-20 \mathrm{~cm}$ soil layer, as previously observed by Jaskulska and Jaskulski [6]. Therefore, alternative soil tillage to conventional plowing, such as spading and subsoiling, appear to be more suitable, mostly because they allow a decrease in external inputs, in terms of reduced fuel consumption, and result in similar crop yield compared with conventional tillage practices, even if their suitability is carefully evaluated based on the different climate, soil and crop conditions [7].

Mineral fertilizers provide a high amount of nutrients that are used for improving crop yield; however, their overuse and repeated applications affect the stability of agroecosystems and their living communities, including weeds [8,9]. Several studies reported that excessive use of mineral fertilizers may lead to the loss of productivity resulted from adverse conditions for crop growth, i.e., high competition for limited resources, loss of fertility, depletion of soil nutrients and environmental pollution [10,11]. Accordingly, the high percentage of nitrogenous fertilizers may cause pollution of surface water and groundwater [12]. In addition, mineral fertilizers, especially nitrogen, may affect certain weeds by breaking their dormancy and thus affect weed species composition, thus, limiting their availability for the crops [13]. Considering that many weeds are high consumers of nitrogen, the application of organic fertilizers, characterized by slow release, reduce the availability of soil nitrogen and, therefore, affect weed demographic processes and crop-weed competitive interactions [13-15]. Among the organic fertilizers, municipal organic waste $(\mathrm{MOW})$ could represent a low-cost alternative nutrient management that may provide several benefits for promoting and enhancing agro-ecosystem health. Indeed, the MOW is mainly composed of properly composted kitchen and yard waste and is used as a way of diverting organic waste materials from landfills while creating a product, at relatively low cost, that is suitable for agricultural purposes. The MOW use in agriculture is growing as soil conditioner and fertilizers to meet crop nitrogen requirements and for increasing the organic matter in the soil. Moreover, by increasing organic $C$ content in the soil, MOW application impacts soil parameters, directly and indirectly. Other benefits include improving soil structure and aggregate stability and promoting more balanced microbial biomass that will act over time as a reserve of mineral elements by retaining them in the surface horizons and gradually releasing to plants [16,17]. Although the adoption of MOW is recommended for the potential benefits in agriculture, its safe use is related to the quality of the materials and metals and salt contents that can generate problems in case of overuse [18].

Durum wheat represents one of the major crops cultivated in the Mediterranean basin, especially in Italy, with notable relevance from an economical and cultural point of view where it is considered a staple crop for many people across the world [19]. When durum wheat is grown in a Mediterranean environment, it often suffers from a soil water deficit in spring, where a low rainfall during the flowering stage causes strong intraspecific competition among wheat plants and weeds, which could noticeably reduce the potential yield of the cereal [20]. Considering that durum wheat is a weak competitor [21,22], it is of great importance to evaluate the weed community composition triggered by management practices, such as soil tillage and fertilization sources, in order to avoid highly competitive weed species that could decrease the yield capacity of the cereal crops [23]. Indeed, according to the findings of Usman et al. [24], weeds represent the major concern 
in wheat-based rotations, and conventional tillage practices deteriorate soil and water quality, resulting in serious concerns about the future potential for productivity growth and long-term sustainability of wheat cultivation. In addition, the application of high levels of mineral nitrogen fertilizers stimulates the growth of weeds more than the growth of crops, resulting in enhanced competitiveness against cultivated plants [13]. Therefore, alternative management practices are needed to maximize crop productivity while minimizing potential negative impacts of weeds $[25,26]$.

From an agro-ecological point of view, the weeds are an important component of the biodiversity [27]. Their ecological role within the system is to support more diversified biota. They can be beneficial to the system by contributing to the recycling of nutrients, increasing the presence of micro-fauna, and regulating the microclimate and local hydrological processes. Furthermore, weed diversity has been suggested to decrease the likelihood of developing herbicide resistant weed communities and provide resources for beneficial organisms and enhance soil quality [28]. Weeds can also impair the performance of the agro-ecosystem, entering strong competition with the crop or becoming a vector of pathogens or insect pests [29]. The optimal weed diversity will be the one without truly dominant species, combined with a low overall density [30]. Despite the importance from an agro-ecological point of view, it is important to keep weed infestation below the harmfulness threshold to avoid severe economic losses by means of soil tillage, fertilization source and herbicide application as a part of an integrated weed management strategy.

Worldwide, wheat cultivation is generally based on intensive soil tillage operations supported by the high rate of nitrogen fertilizers that are detrimental to the agroecosystem's sustainability, also including the loss of biodiversity as weed species composition. Although there are many studies that reported the effect of intensive practices on the weed spectrum, to date, few studies have reported the interaction effects of soil tillage and fertilization sources on weed flora composition. Indeed, the adoption of some alternative agronomical strategies should be adequately evaluated both agronomically and environmentally. A better understanding of these issues could contribute to more effective use of agronomic practices to manage weeds and to support sustainable management practices in the Mediterranean agro-ecosystems. Therefore, this study hypothesized that spading and sub-soiling and organic fertilizers can contribute to maintaining weed diversity in durum wheat cultivation, compared with plowing and mineral fertilizers. The main objectives of this study are: (i) to determine the variation of species composition of weed flora in response to different soil tillage and fertilization sources; (ii) to assess the association of weed flora to different soil tillage and fertilization sources; and (iii) recognition of soil tillage and fertilizer source impact on the yield of durum wheat.

\section{Materials and Methods}

\subsection{Site Description}

Field experiments were carried out in two consecutive growing seasons $(2013 / 2014$ and 2014/2015) of durum wheat at the research farm of the University of Tuscia located in Viterbo, Latium region (lat. $42^{\circ} 42^{\prime}$, long. $12^{\circ} 07^{\prime}$ and alt. $310 \mathrm{~m}$ a.s.1.). In both growing seasons, trials were performed in Entisol soil with sandy-loam texture (USDA) classified as a Typic Xerofluvent of volcanic origin with the following particle size distribution in the first $30 \mathrm{~cm}$ of soil layer: $760 \mathrm{~g} \mathrm{~kg}^{-1}$ of dry sand, $130 \mathrm{~g} \mathrm{~kg}^{-1}$ of dry silt, $110 \mathrm{~g} \mathrm{~kg}^{-1}$ of dry clay (loamy sand). Moreover, the soil was characterized by $0.97 \%$ of organic matter content, $0.15 \%$ total nitrogen and $6.9 \mathrm{pH}\left(\mathrm{H}_{2} \mathrm{O}\right)$. The experimental area is typical of a Mediterranean environment with a mean temperature of $14^{\circ} \mathrm{C}$ and a yearly rainfall of $780 \mathrm{~mm}$ (average of the last 30-year period).

\subsection{Experimental Details}

The study was conducted with the aim of evaluating the spectrum of weed flora in durum wheat subjected to different tillage regimes and fertilizer sources. The field trials were conducted in fields cultivated with potato (Solanum tuberosum L.) in the previous 
year as a crop rotation commonly adopted by the local farmers. The field experiment was arranged in a randomized complete block design with a factorial arrangement of treatments and three replications of each treatment. The experiment included (i) three tillage regimes (conventional tillage performed with moldboard plow (hereafter called Plo), alternative soil tillage performed with subsoiler (hereafter called Sub), and another alternative soil tillage performed with a spading machine (hereafter called SM)), and (ii) two fertilization sources (mineral based on the application of mineral fertilizers (hereafter called MIN) and organic based on the application of municipal organic waste (hereafter called MOW)). The field experiment consists of 18 plots ( 3 soil tillage $\times 2$ fertilizer sources $\times 3$ replications, Figure 1). Each plot had a size of $60 \mathrm{~m}^{2}(6 \times 10 \mathrm{~m})$. Furthermore, 5-m-wide alleys separated all plots of the experimental field to carry out all farming operations.

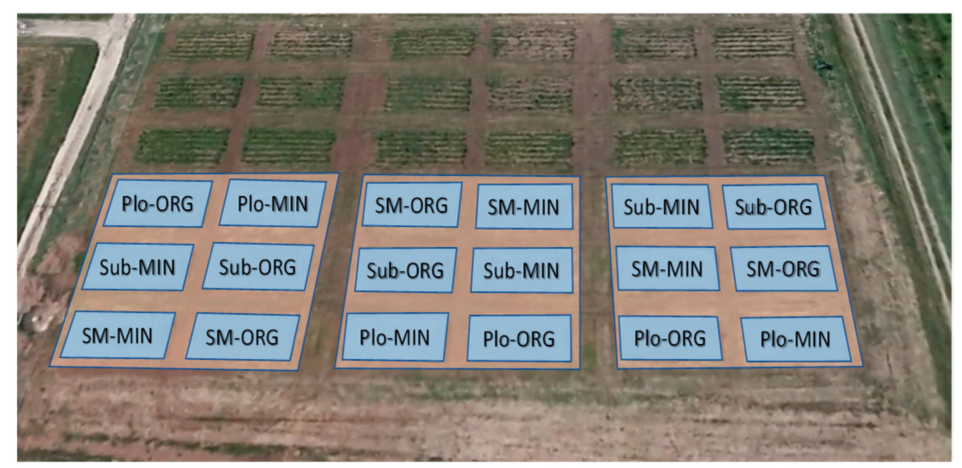

Figure 1. Experimental field plan in the 2013/2014 growing season of durum wheat. MIN = mineral fertilization; MOW = municipal organic waste; Plo = plowing; Sub = subsoiling; $\mathrm{SM}=$ spading machine.

\subsection{Weather Conditions during Durum Wheat Cultivation}

The durum wheat growing season lasted for 218 and 213 days in 2013/2014 and 2014/2015 growing seasons, respectively. The total rainfall was $822 \mathrm{~mm}$ in 2013/2014, uniformly distributed during the whole growing season of durum wheat, except two peaks of 157 and $136 \mathrm{~mm}$ in January and June, respectively (Figure 2). The cumulated precipitation was low $(529 \mathrm{~mm}$ ) in the 2014/2015 growing season, mainly concentrated from November to February, while it was limited in the following period. Air temperatures follow the long-term average trend and gradually decrease after durum wheat sowing until February, and then air temperature gradually increased, reaching the highest temperature before the wheat seed harvesting. The average air temperature was similar between the growing seasons $\left(12.1^{\circ} \mathrm{C}\right)$, minimum temperatures were a bit hotter in 2014/2015 compared with $2013 / 2014$ (on average 7.4 vs. $6.9^{\circ} \mathrm{C}$ ). In both growing seasons, minimum temperatures seldom dropped to $0{ }^{\circ} \mathrm{C}$ in winter, except in January 2014 when air temperature dropped to $0{ }^{\circ} \mathrm{C}$ two times. 

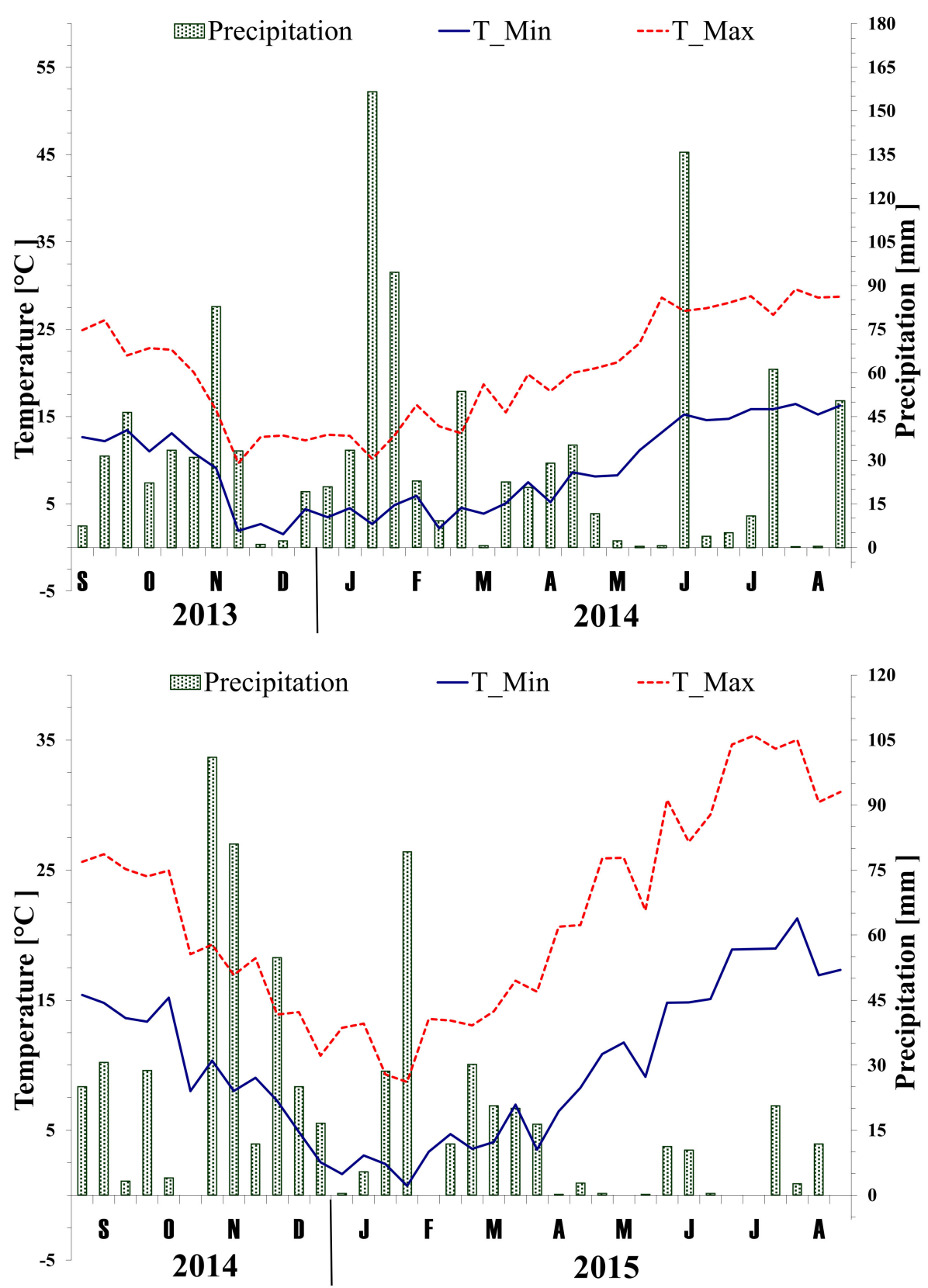

Figure 2. Weather data at 10-day intervals (maximum (red line), minimum (blue line) temperatures $\left({ }^{\circ} \mathrm{C}\right)$ and rainfall (columns, $\left.\mathrm{mm}\right)$ ) at the experimental site during the experimental period in 2013/2014 and 2014/2015 growing seasons of durum wheat.

\subsection{Crop Management}

The seedbed of durum wheat was prepared in September of each growing season according to the selected soil tillage treatments. All main tillage (Plo, Sub and SM) were done up to $20 \mathrm{~cm}$ of the soil layer and then followed by a disk harrowing up to $10 \mathrm{~cm}$ of soil depth performed twice until durum wheat sowing. The machines used in Plo, Sub and SM treatments were Angeloni APS M35 [31], Dondi RHP-5M [32] and Tortella 005-100 [33], respectively. In mineral fertilizer source, fertilization practices were performed according to the local practices by applying the total amount of $80 \mathrm{~kg}$ of $\mathrm{P}_{2} \mathrm{O}_{5} \mathrm{ha}^{-1}$ as a triple superphosphate applied before the last disk harrowing for seedbed preparation and a total of $120 \mathrm{~kg}$ of $\mathrm{N} \mathrm{ha}^{-1}$ divided into three rates according to the common practices adopted by the farmers of the area: the first $\mathrm{N}$ application $\left(30 \mathrm{~kg}\right.$ of $\mathrm{N} \mathrm{ha}^{-1}$ as a calcium nitrate) was carried out at the beginning of the tillering stage in January; the second $\mathrm{N}$ application 
(40 $\mathrm{kg}$ of $\mathrm{N} \mathrm{ha}^{-1}$ as ammonium nitrate) was distributed at the end of the tillering stage in February; and the last $\mathrm{N}$ application ( $50 \mathrm{~kg}$ of $\mathrm{N} \mathrm{ha}^{-1}$ as urea) was applied at the beginning of stem elongation in March. In the organic fertilizer, municipal organic waste was applied at the rate of $10,000 \mathrm{~kg} \mathrm{ha}^{-1}$ to apply the same amount of nitrogen applied in the mineral fertilizer treatments. The rate of organic fertilizer application was calculated considering the theoretical mineralization of MOW considering the demand of $120 \mathrm{~kg}_{\mathrm{o} \mathrm{N} \mathrm{ha}}{ }^{-1}$ as common practices adopted by the farmers. The characteristics of the MOW fertilizer are reported in Table 1. The chemical analysis of MOW showed that all heavy metals are widely below the legal limits (Table 1). The MOW fertilizer was applied before the last disk harrowing for the seedbed preparation.

Table 1. Chemical and physical characteristics of municipal organic waste (MOW) adopted in the experiments and admitted limits based on D.lgs 75/2010.

\begin{tabular}{|c|c|c|c|}
\hline Parameter & Methodology & Values & Limit \\
\hline Moisture (\%) & DM 21/12/2000 GU n. 21 26/01/2001 & 19.4 & $<50$ \\
\hline $\mathrm{pH}$ & DM 17/06/2002 GU n. 220 del 19/09/2002 suppl.7 Met III.4 & 7.8 & $6-8.8$ \\
\hline Conductivity $\left(\mathrm{dS} \mathrm{m}^{-1}\right)$ & DM 17/06/2002 GU n. 220 del 19/09/2002 suppl.7 Met III.4 & 3.82 & - \\
\hline Organic carbon (\%) & DM 13/09/1999 SO n. 185 GU n. 248 21/10/1999 Met. VII.1 & 25.7 & $>20$ \\
\hline Organic nitrogen $(\%)$ & DM 13/09/1999 SO n. 185 GU n. 248 21/10/1999 Met. VII.1 & 2.37 & - \\
\hline $\mathrm{C} / \mathrm{N}$ ratio & DM 13/09/1999 SO n. 185 GU n. 248 21/10/1999 Met. VII.1 & 10.7 & $<25$ \\
\hline Phosphorous & EPA 30521996 + EPA 6010D2018 & 0.5 & - \\
\hline Cadmium (mg kg $\left.{ }^{-1} \mathrm{DM}\right)$ & EPA 30521996 + EPA 6010D2018 & $<1.0$ & $<1.5$ \\
\hline Copper $\left(\mathrm{mg} \mathrm{kg}^{-1} \mathrm{DM}\right)$ & EPA 30521996 + EPA 6010D2018 & 70.1 & $<230$ \\
\hline Mercury (mg kg $\left.{ }^{-1} \mathrm{DM}\right)$ & EPA 74732007 & 0.10 & $<1.50$ \\
\hline Nickel (mg kg $\left.{ }^{-1} \mathrm{DM}\right)$ & EPA 30521996 + EPA 6010D2018 & 16.8 & $<100$ \\
\hline Lead (mg kg $\left.{ }^{-1} \mathrm{DM}\right)$ & EPA 30521996 + EPA 6010D2018 & 34.5 & $<140$ \\
\hline Zinc (mg kg $\left.{ }^{-1} \mathrm{DM}\right)$ & EPA 30521996 + EPA 6010D2018 & 146.0 & $<500$ \\
\hline Chrome VI (mg kg $\left.{ }^{-1} \mathrm{DM}\right)$ & DM 08/05/2003 Suppl.8 GU n. 116 21/05/03 & $<0.10$ & $<0.5$ \\
\hline
\end{tabular}

Durum wheat, cv. "Claudio", was sown on the same day in all treatments on 27th November 2013 and 25th November 2014 by means of experimental planter (Plotseed TC-Wintersteiger AG, Ried im Innkreis, Austria) at the seed density of 450 seeds $\mathrm{m}^{-2}$ with row distance of $12.5 \mathrm{~cm}$ and about $3 \mathrm{~cm}$ of depth. Weeds were managed by means of herbicide (Mesosulfuron-Metile 3\% + Iodosulfuron. Metil-Sodium 3\% + Mefenpir-Dietile $9 \%$ ) applied at the end of wheat tillering in all treatments, as commonly applied by the farmers of the area. Durum wheat was harvested at physiological maturity of kernels on 3 July 2014 and 26 June 2015.

\subsection{Observations}

Weed biomass and weed density (total and specific) were taken the day before herbicide application in all plots. A sampling area of $0.25 \mathrm{~m}^{2}(0.5 \times 0.5 \mathrm{~m})$ was placed randomly four times, for a total of $1 \mathrm{~m}^{2}$, in a uniform area inside each plot to record weed diversity and density. Weeds were uprooted manually and then divided per species in order to determine weed species composition and specific weed species density. Total weed density was obtained by adding the specific densities of all species, while the total weed biomass was evaluated by weighing the whole sample from each plot after oven-dried at $80^{\circ} \mathrm{C}$ until constant weight. At durum wheat physiological maturity, the whole aboveground biomass from four 2-m long adjacent rows $\left(1 \mathrm{~m}^{2}\right)$, harvested in the center of each plot, was collected by hand clipping the wheat plant at ground level and analyzed for evaluating yield and yield components. 


\subsection{Data Analysis}

Statistical analysis was carried out by performing analysis of variance (ANOVA) among the observed data. The variance analysis of field data was carried out using the software JMP v. 4.0 [34] for the 2-year period applying a randomized complete block design with three replications. A Bartlett test was performed to test if data have equal variance [35]. Weed density data were square root transformed $(x+0.5)$ before analysis in order to homogenize the variance (Gomez and Gomez, 1984). Data reported in the tables are back transformed. A two-way factorial experimental design was performed for weed and wheat characteristics where soil tillage and fertilization source were the treatments, and the growing season was considered as the repeated measure. Fisher's protected least significant differences (LSD) at the probability of $0.05(p \leq 0.05)$ was adopted to compare the main and interaction effects.

The multi-response permutation procedure (MRPP) was applied to test whether there was a significant difference between weed species composition among soil tillage and fertilizer source groups, as suggested by McCune and Grace [36]. The MRPP provides a $\mathrm{T}$-statistic that describes the separation among groups (the more negative $\mathrm{T}$ is, the stronger the separation is) and its associate significance. The MRPP analysis was carried out using the BLOSSOM software [37]. Moreover, the canonical discriminant analysis (CDA) was applied to identify the associations between each weed species with the soil tillage and fertilizer source. The result of CDA analysis was reported in a two-dimensional canonical discriminant structure plot, where the appearance of weed species and treatments in the same ordination space indicates association between them. The size of the standardized discriminant function coefficient associated with each variable indicates the contribution of that weed species to the discriminant function (soil tillage or fertilizer source).

\section{Results}

\subsection{Weed Characteristics in Durum Wheat}

There was an interaction between soil tillage regimes and fertilization sources for weed density and aboveground biomass during both growing seasons of durum wheat (Supplementary Table S1). Weed density observed in the field study ranged from 67.3 to 34.3 plants $\cdot \mathrm{m}^{-2}$, and it was higher in 2013/2014 compared with the 2014/2015 growing season (on average 51.3 vs. 46.5 plants $\cdot \mathrm{m}^{-2}$, respectively). Moreover, weed density was greater in MOW than the MIN fertilization source (on average 53.8 vs. 44.0 plants $\cdot \mathrm{m}^{-2}$, respectively). Differences were evident among all soil tillage treatments in 2014/2015 and only under Sub treatment in 2013/2014 (Table 2). The weed density observed in Sub tillage was the highest regardless of the fertilization (on average 58.2 plants $\mathrm{m}^{-2}$ ) and was intermediate in SM and low in Plo under the MOW fertilization source, while similar values were detected between Plo and SM under the MIN fertilization source in both growing seasons (Table 2). Weed aboveground biomass was the highest in Sub-MOW 2014/2015 (94.0 $\mathrm{g} \cdot \mathrm{m}^{-2}$ of DM) and the lowest in Plo-MIN in 2014/2015 $\left(42.5 \mathrm{~g} \cdot \mathrm{m}^{-2}\right.$ of DM) and showed a similar trend to that described for weed density. Furthermore, it was higher in 2013/2014 than 2014/2015 (66.2 vs. $63.0 \mathrm{~g} \cdot \mathrm{m}^{-2}$ of DM, respectively). Although the weed biomass was higher in MOW compared with MIN fertilization source (on average 72.4 vs. $56.8 \mathrm{~g} \cdot \mathrm{m}^{-2}$ of DM, respectively), the main differences between fertilizer sources were observed in the 2014/2015 growing season regardless of the soil tillage practice. Inversely, in 2013/2014, growing season weed biomass was higher in MOW than MIN only under SM tillage, while similar values were observed under Sub and Plo soil tillage systems (Table 2). Generally, in both growing seasons and fertilizer sources, weed biomass was the highest under S tillage followed by SM than Plo tillage (on average 77.4, 61.1 and $55.3 \mathrm{~g} \cdot \mathrm{m}^{-2}$ of DM, respectively), except in 2013/2014-MOW where the weed biomass was higher under Sub and similar between Plo and SM tillage regimes (Table 2). In both growing seasons of durum wheat, weed flora composition was mainly composed of annual species compared with perennial ones (on average 41.0 vs. 7.9 plants $\cdot \mathrm{m}^{-2}$, respectively, Table 3). The data analysis showed that the number of annual weed species was affected only by soil tillage 
treatments $(p<0.05$, Supplementary Table S1). In fact, annual weeds were similar among both fertilizer sources, and they were high in Sub, intermediate in SM and low in Plo tillage $\left(43.5,40.0\right.$, and 39.4 plants $\cdot \mathrm{m}^{-2}$, respectively). Perennial weed species were affected by soil tillage $\times$ fertilization source (Plo $<0.05$, Supplementary Table S1) and tended to be higher in MOW than MIN fertilizer sources (on average $8.9 \mathrm{vs} .6 .9 \mathrm{n} \cdot \mathrm{m}^{-2}$, respectively), even if the main differences were observed under Sub tillage (Table 3). In both fertilization source treatments, the perennial weed species were the highest in Sub followed by SM and Plo tillage (on average $14.7,6.8$, and 2.2 plants $\cdot \mathrm{m}^{-2}$, respectively).

Table 2. The interaction effect of year $\times$ fertilization source $\times$ soil tillage on the weed density and weed aboveground biomass in durum wheat. Values followed by the same lower-case letters in columns are not different according to LSD (0.05). Values followed by the same upper-case letters in rows (within year) are not different according to LSD (0.05). MIN = mineral fertilization; $\mathrm{MOW}=$ municipal organic waste; $\mathrm{Plo}=$ plowing; $\mathrm{Sub}=$ subsoiling; $\mathrm{SM}=$ spading machine . LSD = least significant differences.

\begin{tabular}{|c|c|c|c|c|c|c|c|c|}
\hline & \multicolumn{4}{|c|}{$\begin{array}{l}\text { Weed Density } \\
\left(\text { plants } \cdot \mathbf{m}^{-2}\right)\end{array}$} & \multicolumn{4}{|c|}{$\begin{array}{l}\text { Weed Aboveground Biomass } \\
\qquad\left(\mathrm{g} \cdot \mathrm{m}^{-2}\right)\end{array}$} \\
\hline & \multicolumn{2}{|c|}{$2013 / 2014$} & \multicolumn{2}{|c|}{$2014 / 2015$} & \multicolumn{2}{|c|}{$2013 / 2014$} & \multicolumn{2}{|c|}{$2014 / 2015$} \\
\hline & MIN & MOW & MIN & MOW & MIN & MOW & MIN & MOW \\
\hline Plo & $44.3^{\mathrm{bA}}$ & $46.0^{\mathrm{bA}}$ & $34.3^{\mathrm{bB}}$ & $42.0^{\mathrm{cA}}$ & $54.1^{\mathrm{bA}}$ & $55.0^{\mathrm{cA}}$ & $42.5^{\mathrm{cB}}$ & $69.6^{\mathrm{cA}}$ \\
\hline Sub & $56.3^{\mathrm{aB}}$ & $63.7^{\mathrm{aA}}$ & $45.3^{\mathrm{aB}}$ & $67.3^{\mathrm{aA}}$ & $75.6^{\mathrm{aA}}$ & $77.0^{\mathrm{aA}}$ & $62.8^{\mathrm{aB}}$ & $94.0^{\mathrm{aA}}$ \\
\hline $\mathrm{SM}$ & $47.0^{\mathrm{bA}}$ & $50.3^{\mathrm{bA}}$ & $36.7^{\mathrm{bB}}$ & $53.3^{\mathrm{bA}}$ & $54.3^{\mathrm{bB}}$ & $61.9^{\mathrm{bA}}$ & $51.2^{\mathrm{bB}}$ & $77.0^{\mathrm{bA}}$ \\
\hline LSD & \multicolumn{4}{|c|}{7.21} & \multicolumn{4}{|c|}{6.34} \\
\hline
\end{tabular}

Table 3. The main effect of soil tillage on annual and monocot weeds and the interaction effect of fertilization source $x$ soil tillage on perennial and dicot weeds in durum wheat. Values followed by the same lower-case letters in columns are not different according to LSD (0.05). Values followed by the same upper-case letters in rows (within fertilization source) are not different according to LSD (0.05). $\mathrm{MIN}=$ mineral fertilization; $\mathrm{MOW}=$ municipal organic waste; $\mathrm{Plo}=$ plowing; $\mathrm{Sub}=$ subsoiling; $\mathrm{SM}=$ spading machine; $\mathrm{LSD}=$ least significant differences.

\begin{tabular}{|c|c|c|c|c|c|c|c|c|}
\hline & & & \multicolumn{6}{|c|}{$\begin{array}{l}\text { Weed Density Characteristics } \\
\left.\text { (plants } \cdot \mathrm{m}^{-2}\right)\end{array}$} \\
\hline & \multicolumn{2}{|c|}{ Annual } & \multicolumn{2}{|c|}{ Perennial } & \multicolumn{2}{|c|}{ Monocots } & \multicolumn{2}{|c|}{ Dicots } \\
\hline & MIN & MOW & MIN & MOW & MIN & MOW & MI & MOW \\
\hline Plo & $37.0^{\mathrm{aB}}$ & $41.8^{\mathrm{bA}}$ & $2.3^{\mathrm{cA}}$ & $2.1^{\mathrm{cA}}$ & $3.7 \mathrm{aB}$ & $9.3^{\mathrm{bA}}$ & $30.0^{b B}$ & $40.3^{\mathrm{cA}}$ \\
\hline Sub & $38.7^{\mathrm{aB}}$ & $48.3^{\mathrm{aA}}$ & $12.2^{\mathrm{aB}}$ & $17.2^{\mathrm{aA}}$ & $6.8^{\mathrm{aB}}$ & $13.3^{\mathrm{aA}}$ & $37.5^{\mathrm{aB}}$ & $58.7^{\mathrm{aA}}$ \\
\hline $\mathrm{SM}$ & $35.6^{\mathrm{aB}}$ & $\begin{array}{l}44.3 \\
\mathrm{abA}\end{array}$ & $6.1^{\mathrm{bA}}$ & $7.5^{\mathrm{bA}}$ & $4.5^{\mathrm{aB}}$ & $13.3^{\mathrm{aA}}$ & $29.5^{b B}$ & $47.3^{\mathrm{bA}}$ \\
\hline LSD & \multicolumn{2}{|c|}{5.94} & 1.42 & \multicolumn{3}{|c|}{3.78} & \multicolumn{2}{|c|}{2.81} \\
\hline
\end{tabular}

The density of dicots weed species was higher compared to monocots species (on average 40.6 vs. 8.7 plants $\cdot \mathrm{m}^{-2}$, respectively). The dicots weed species were affected by soil tillage $x$ fertilization source interaction $(p<0.05$, Supplementary Table S1). The dicot weed species were higher in 2013/2014 than 2014/2015 growing seasons (41.8 vs. 39.3 plants $\cdot \mathrm{m}^{-2}$, respectively). Dicot weed density was greater in MOW than MIN fertilizer sources (on average 48.8 vs. 32.3 plants $\cdot \mathrm{m}^{-2}$, respectively); moreover, they tended to be the highest under Sub tillage, intermediate in SM and low in Plo tillage (on average 48.1, 38.4, and 35.2 plants $\cdot \mathrm{m}^{-2}$, respectively), but under MIN fertilizer sources, SM and Plo tillage showed similar values to dicots weed species (Table 3). The monocots species were affected by only the soil tillage treatments $(p<0.05)$ and their density was higher and 
similar under both Sub and SM tillage (on average 9.8 plants $\mathrm{m}^{-2}$ ) compared with Plo tillage (6.5 plants $\left.\mathrm{m}^{-2}\right)$.

The results of the MRPP analysis suggested that in both growing seasons of durum wheat, the MIN and MOW fertilization source groups were characterized by different vegetation assemblages; however, the magnitude of the differences ( $T$ value) in 2013/2014 was higher than $2014 / 2015$ ( -5.73 vs. -3.61 , respectively, Table 4 ). The canonical discriminant analysis on the weed species observed at the end of durum wheat tillering was in accordance with the MRPP analysis, and it showed that the first two canonical variables explained $67 \%$ of the total variance for fertilizer source treatments (Figure 3A). Indeed, the CDA analysis showed that monocot weed species such as Lolium perenne, Avena sterilis, Phalaris minor, Phalaris canariensis were associated with MIN fertilizer sources together with Galium aparine and Convolvolus arvensis. Conversely, the vectors of most of the dicots weed species were located in the same orientation space of MOW fertilizer sources (Figure 3A).

Table 4. Test statistic from the multi-response permutation procedure (MRPP) for multiple paired comparisons to evaluate the main effects of fertilization source and soil tillage on the density of each weed species that determined the floristic composition in 2013/2014 and 2014/2015 observed in durum wheat. $\mathrm{P}$ is the probability of significant differences among selected groups. $\mathrm{T}$ is the T-statistic. $\mathrm{MIN}=$ mineral fertilization; $\mathrm{MOW}=$ municipal organic waste; Plo = plowing; Sub = subsoiling; $\mathrm{SM}=$ spading machine.

\begin{tabular}{lcccc}
\hline & \multicolumn{2}{c}{$\mathbf{2 0 1 3 / 2 0 1 4}$} & \multicolumn{2}{c}{$\mathbf{2 0 1 4 / 2 0 1 5}$} \\
\cline { 2 - 5 } & T & $p$ & T & $p$ \\
\hline Fertilization & & & & \\
MIN vs. MOW & -5.73 & $<0.0001$ & -3.61 & 0.0041 \\
Soil tillage & & & & \\
Plo vs. SM & -0.58 & 0.2368 & -0.09 & 0.5134 \\
Plo vs. Sub & -2.63 & 0.0225 & -3.91 & 0.0029 \\
SM vs. Sub & -0.26 & 0.3468 & -1.43 & 0.0883 \\
\hline
\end{tabular}

The results of the Multi-Response Permutation Procedure (MRPP) showed that the T-statistic for defined groups of soil tillage were negative and significant when plow (Plo) was compared with subsoiler (Sub) in both growing seasons, while no significant differences were observed between P vs. spading machine (SM) and SM vs. Sub multiple paired comparisons (Table 3). The CDA on the weed species observed at the end of durum wheat tillering was in accordance with the MRPP analysis, and it showed that the first two canonical variables explained $73 \%$ of the total variance for soil tillage treatments (Figure 3B). Based on the tillage treatments, Lolium perenne, Sonchus arvensis, Papaver rhoeas, Matricaria camomilla, Fumaria officinalis, Fallopia convolvulus, Rapistrum rugosum, Chrysantemum segetum, Avena sterilis, Cirsium arvensis and Galium aparine were associated with subsoiler tillage, while Anagallis arvensis, Centaurea cyanus, Phalaris canariensis and Sylibum marianum were associated with spading soil tillage and Capsella bursa-pastoris, Sinapis arvensis, Stellaria media and Veronica hederifolia were associated with plough soil tillage (Figure 3B). 

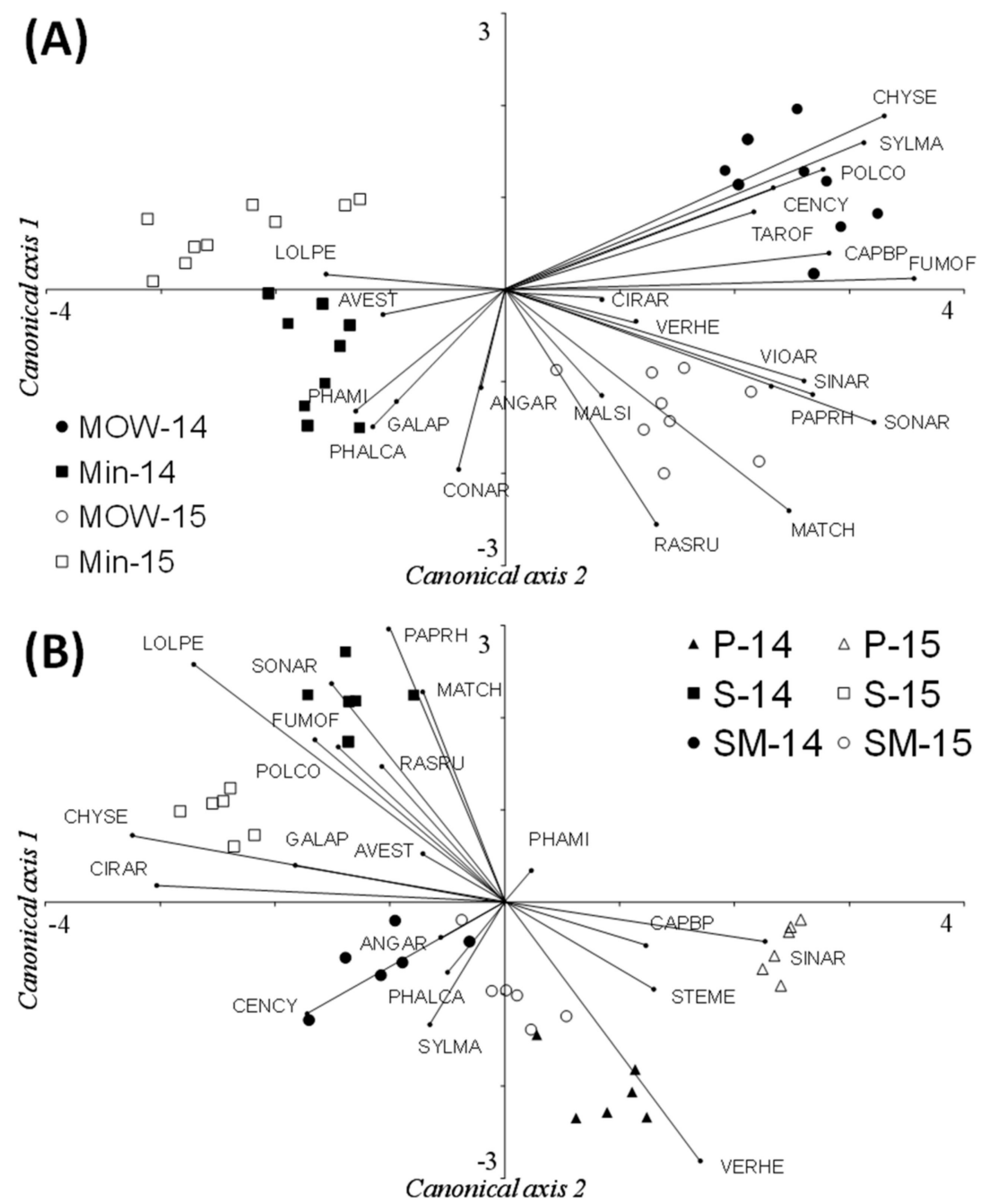

Figure 3. Canonical discriminant analysis (CDA) of the weed species based on fertilizer sources (A) and soil tillage (B) in 2013/2014 and 2014/2015 observed in durum wheat. MIN = mineral fertilization; $\mathrm{MOW}=$ municipal organic waste; $\mathrm{Plo}=$ plowing; Sub = subsoiling; $\mathrm{SM}=$ spading machine. VIOAR = Viola arvensis; FUMOF = Fumaria officinalis; CENCY = Centaurea cyanus; MATCH = Matricaria camomilla $;$ POLCO = Fallopia convolvolus; GALAP = Galium aparine; ANGAR = Anagallis arvensis; STEME = Stellaria media VERHE = Veronica hederifolia $;$ PAPRH = Papaver rhoeas; RASRU = Rapistrum rugosum; CHYSE = Chrysantemum segetum; SINAR = Sinapis arvensis; SYLMA = Sylibum marianum; CAPBP = Capsella bursa-pastoris; MALSI = Malva sylvestris; CIRAR = Cirsium arvensis; $\mathrm{SONAR}=$ Sonchus arvensis; TAROF $=$ Taraxacum officinalis; CONAR = Convolvolus arvensis; $\mathrm{PHAMI}=$ Phalaris minor $; \mathrm{APESV}=$ Apera spica-venti; $\mathrm{AVEST}=$ Avena sterilis $; \mathrm{PHACA}=$ Phalaris canariensis; LOLPE = Lolium perenne.

\subsection{Durum Wheat Yield}

There were significant interactions for year $\times$ fertilization source $\times$ soil tillage on the durum wheat yield (Figure 4). The durum wheat yield varied from $607.0 \mathrm{~g} \cdot \mathrm{m}^{-2}$ in 2013/2014-MIN-Plo to $297.0 \mathrm{~g} \cdot \mathrm{m}^{-2}$ in 2014/2015-MOW-Sub. Grain yield was generally higher in 2013/2014 compared with 2014/2015 (on average 457.1 vs. $443.3 \mathrm{~g} \cdot \mathrm{m}^{-2}$, respectively). Moreover, it was higher in MIN than the MOW fertilization source (on average 542.1 vs. $360.0 \mathrm{~g} \cdot \mathrm{m}^{-2}$, respectively), except in 2014/2015-SM where no differences were detected between MIN and MOW fertilization sources (Figure 4). In both growing seasons, grain yield of durum wheat was higher in the Plo tillage under the MIN fertilization source followed by Sub and SM soil tillage (on average $587.7,532.9$ and $505.7 \mathrm{~g} \cdot \mathrm{m}^{-2}$, respectively). Conversely, in MOW treatments, the greater grain yield was observed in SM tillage com- 
pared with Sub and Plo tillage treatments (on average $427.9 \mathrm{vs.} 326.1 \mathrm{~g} \cdot \mathrm{m}^{-2}$, respectively). Durum wheat straw followed the same trend to that described for the grain yield, and it was generally higher in 2013/2014 than $2014 / 2015$ (on average $718.8 \mathrm{vs} .653 .9 \mathrm{~g} \cdot \mathrm{m}^{-2}$, respectively) and in MIN fertilizers sources compared with MOW (on average 794.9 vs. $577.8 \mathrm{~g} \cdot \mathrm{m}^{-2}$, respectively). Among the soil tillage practices, the straw was greater in Plo and Sub than SM in 2013/2014 (on average 911.9 vs. $747.5 \mathrm{~g} \cdot \mathrm{m}^{-2}$, respectively), and similar values were observed among the soil tillage systems in 2014/2015-MIN (on average $732.6 \mathrm{~g} \cdot \mathrm{m}^{-2}$, Table 4). Among the MOW fertilization sources, wheat straw was the highest in 2014/2015-MOW-SM compared with the other soil tillage treatments (on average 726.9 vs. $499.3 \mathrm{~g} \cdot \mathrm{m}^{-2}$, respectively), while the straw was similar among all soil tillage treatments (Figure 4).
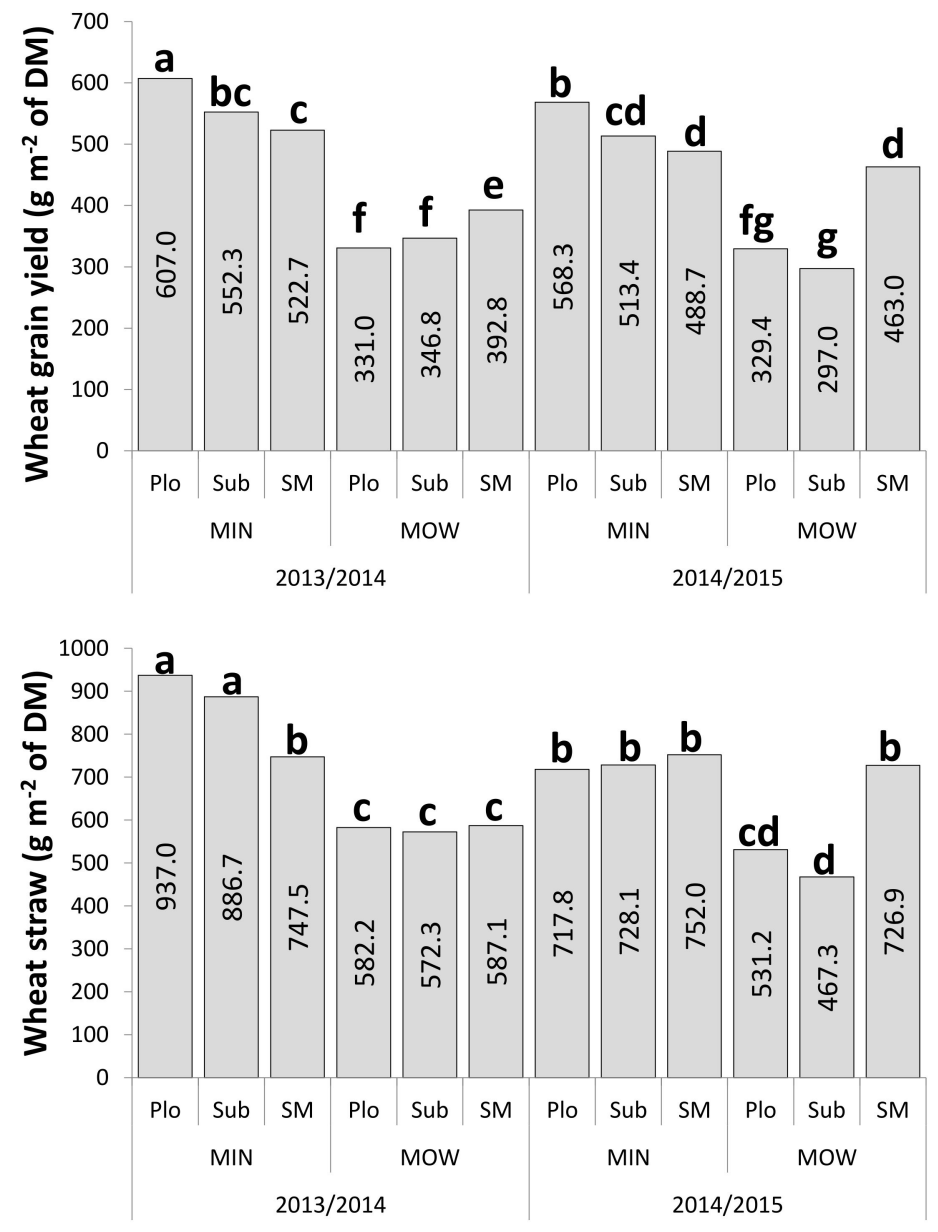

Figure 4. The interaction effect of year $\times$ fertilization source $\times$ soil tillage on the grain yield and straw of durum wheat. Values within either grain yield or straw followed by the same letter are not significantly different according to LSD (0.05). MIN = mineral fertilization; $\mathrm{MOW}=$ municipal organic waste; $\mathrm{Plo}=$ plowing; Sub = subsoiling; $\mathrm{SM}=$ spading machine.

\section{Discussion}

The results agree with those of Zanin et al. [38], which show a significant interaction between soil tillage regimes and fertilization sources on weed community composition in durum wheat. Similarly, Campiglia et al. [23] showed that the density and biomass of weeds tend to be higher under alternative tillage practices, such as subsoiler, and after organic fertilization. Conversely, low weed diversity tends to be typical of intensively managed soils, as stated by Nichols et al. [39], highly disturbed environments tend to be simpler than more stable ones. 
The analyses showed a total of 25 different species, most of which were annual $(76 \%)$ and dicotyledonous $(80 \%)$, even if a significant correlation has been found between the annual monocots species and the conventionally tilled soil (plowing) [40]. Similarly, Nichols et al. [39] reported that annual broadleaves weeds are favored under high disturbance environments, such as conventionally tilled soil, while perennial weeds can successfully grow under low disturbance environments. It is well known that the plowing through the moldboard causes a complete overturning of the soil clods, deeply burying the majority of weed seeds, which will become dormant [41,42]. However, at the same time, another large section of weed seeds will be brought to the surface and subjected to bad weather, which will reduce their germination rate [43]. Furthermore, by plowing, the reproductive root system of some noxious perennial weed species, such as Cirsium arvensis, will be inactivated, reducing the presence of these kinds of perennial weeds in the community of plowed soil practices. Perennial dicots were mainly associated with alternative soil tillage, such as subsoiling and a spading machine, adopted for seedbed preparation of durum wheat. In the case of soil tillage that does not involve a complete inversion of the soil clods, such as subsoiling, the effect will tend to be less marked with regard to the germinability of the weed seeds of annual species and the survival of reproductive root systems of perennial weed species [44]. Similarly, the spading machine only worked the soil to a depth of $20 \mathrm{~cm}$, thereby keeping the weed seeds in the active layer of the soil where they can easily germinate. Moreover, the presence of some perennial weed species under spading machine treatments could be explained by the effect of spading that chopped and spread the reproductive parts of the plants, such as stolons or rhizomes, resulting in an increased density.

With regards to the fertilization sources, it is well-known that different sources of fertilizer can change the efficiency and availability of nutrients in the soil and, therefore, the development of the weed community. Manipulation of crop fertilization may represent a promising agronomic means for managing weed interference in crops [13]. In general, fertilizers, especially nitrogen fertilizers, are more beneficial to weeds than crops as they show greater responsiveness to timing and application methods, as observed by Blackshaw in spring wheat [15]. In fact, nitrogen stimulates seeds of some weed species by breaking dormancy and, thus, has a considerable impact on the composition of infesting flora [44]. According to the findings of Blackshaw et al. [45], under high soil nitrogen availability, nitrophilous weed species were more responsive than wheat, reducing the amount of nitrogen available to the crop and increasing the competitive ability of those weeds. They may affect competition between plants, alter the density of the seed bank and affect the susceptibility to herbicides of certain weed species [46,47]. Mineral fertilizers benefit weeds with rapid growth rate, as in the case of monocotyledonous, such as Avena sterilis and Phalaris spp., and annual plants, such as Galium aparine and Convolvolus arvensis, which are well-known as nitrophilous species [20,23]. Moreover, Blackshaw et al. [45] observed that the application of mineral nitrogen fertilizers results in an increase of the seedbank of nitrophilous weed species resulting in a potential risk in the long-term run. On the other hand, organic fertilizers can also increase the composition of the weed community because of changing the physical and chemical properties of the soil. Although the nitrogen rate was the same between both fertilizer sources, it is conceivable that the soil nitrogen content for the crop was lower in organic source compared with the mineral fertilizer. The reduced soil nitrogen availability, based on the mineralization rate of organic materials, also favors non-nitrophilous species; therefore, a wide composition of weed community is expected [29]. This is in accordance with the findings of Hyvönen et al. [48], who observed a higher mean species number of weed communities in organic than conventional cropping systems. The increased weed community composition results in different weed types, for instance, dicotyledonous and monocotyledonous, that place plants in different ecological niches and cause the competition in a high biodiversity system to be lower than a single dominant weed would have. However, the fertilizer source is not the only agronomical factor affecting the community composition of weed species. The application method and 
timing of the fertilizer could result in changes of weed flora [49]. For example, increasing nutrient levels can reduce the abundance of weeds but select a few species that will become more competitive. Some weed species prefer $\mathrm{N}-$ such as Avena fatua-or $\mathrm{P}-$ such as Solanum nigrum, while others are more sensitive to other micro and macro-nutrients [44]. In addition, a diffuse surface application can benefit plants that sprout in the surface part of the soil, such as most annual plants [50].

According to Siddiqui et al. [51], the highest productions of grain and straw were obtained in conventional management (MIN-Plo), while grain yield was always lower under organic fertilization source regardless of the soil tillage adopted. Nevertheless, the values of grain and straw in the 2014/2015 growing season in the case of MOW-SM were found to be similar to values obtained for MIN-Plo to straw but were lower for yield. These results may be related to climatic effects and, in particular, to the rainfall regime of the respective growing years. In fact, the grain yield gap observed between fertilizer sources was probably due to the high precipitation, especially during the grain filling stage, which increased the loss of mineral nitrogen via leaching, reducing the possibility to be used for the crop. This conclusion is supported by the grain yield observed in the 2014/2015 growing season when rainfall was limited and similar to the long-term period and, thus, the availability of soil nitrogen was enough to satisfy the requirements of the cereal crop regardless of the fertilizer source. Similar findings have been previously observed by Campiglia et al. [20]. In these conditions, spading tillage seems to ensure stable grain yield in both fertilization regimes, even if it was always lower than that observed under MIN-P. The adoption of an increased number of organic fertilizers or the integration of organic fertilizers with lower rates of mineral fertilizer could be advisable to compensate for the lack of available nitrogen.

Although the conventional management, such as plowing and mineral fertilization, has resulted in higher grain yield compared with alternative cropping systems, it seems to lead to a selective weed condition that, in the long run, could weaken the resilience of the system by gradually selecting the most competitive weed species that are more difficult to manage, as already observed in previous studies [23,52-54]. In the case of alternative management practices, such as subsoiling and organic fertilization, it is well known that they may benefit the health of the soil $[23,39]$. In fact, the integration of these agronomical practices contributes to synergistic outcomes that include improved soil conditions as well and more diverse weed communities. Therefore, organic fertilizer and alternative tillage, particularly spading, can be used to improve the sustainability of cropping systems in the long term [55].

\section{Conclusions}

The results presented in this study showed that the wheat grain yield is reduced when organic fertilizer and alternative tillage are practiced. Considering that grain yield is the main parameter that makes sense for the farmers and is the reason the wheat is cultivated, these results apparently do not make any case for moving away from traditional intensive agriculture. However, the adoption of intensive practices, such as plowing, associated with mineral nitrogen fertilization may affect weed species composition by promoting a reduction of weed community, which is mainly composed of annual competitive weeds, at the expense of the wheat yield, especially in the long-term period. Conversely, the adoption of alternative tillage practices is more favorable to increase the composition of weed species composed of a wide range of weeds that are more balanced in terms of competition with the crop and preserve the biodiversity of the agro-ecosystems and therefore contribute to maintaining its sustainability. In particular, the adoption of subsoiler showed the highest diversity of weed flora, even if spading tillage may represent the optimal compromise to preserve weed biodiversity and maintain satisfactory durum wheat yield. Furthermore, the mineral nitrogen, not immediately used by the wheat plants after the fertilization, remains available in the soil, stimulating the establishment of nitrophilous weeds well-known as competitive. In this sense, the adoption of organic fertilizer gradually releases nitrogen 
throughout the mineralization process triggered by several agro-environmental factors allowing a higher weed species composition and reducing the environmental risks due to nitrogen leaching. In particular, the combination of spading tillage with the organic fertilizer encourages weed biodiversity and is, therefore, considered to be preferable when sustainable agriculture needs to be adopted to benefit the entire agro-ecosystem.

Supplementary Materials: The following are available online at https:/ /www.mdpi.com/article/10 $.3390 /$ su13137307/s1. Table S1: Analysis of variance summary of weed characteristics and durum wheat yield and straw across the field experiments in the 2013/2014 and 2014/2015 growing seasons.

Author Contributions: Conceptualization, E.R. and R.M.; methodology, E.R. and R.M.; software, R.M.; validation, E.R., R.M., V.P., A.S.L. and M.A.; formal analysis, E.R. and R.M.; investigation, R.M. and E.R.; resources, R.M.; data curation, E.R. and V.P.; writing-original draft preparation, V.P. and E.R.; writing-review and editing, V.P., E.R., A.S.L., M.A. and R.M.; visualization, E.R.; supervision, R.M. All authors have read and agreed to the published version of the manuscript.

Funding: This research received no external funding.

Institutional Review Board Statement: Not applicable.

Informed Consent Statement: Not applicable.

Data Availability Statement: Not applicable.

Conflicts of Interest: The authors declare no conflict of interest.

\section{References}

1. Holling, C.S. Resilience and Stability of Ecological Systems. In The Future of Nature: Documents of Global Change; Yale University Press: New Haven, CT, USA, 2013; ISBN 9780300184617.

2. Hobbs, P.R.; Sayre, K.; Gupta, R. The role of conservation agriculture in sustainable agriculture. Philos. Trans. R. Soc. B Biol. Sci. 2008, 363, 543-555. [CrossRef] [PubMed]

3. Grace, P.R.; Harrington, L.; Jain, M.C.; Philip Robertson, G. Long-Term Sustainability of the Tropical and Subtropical Rice-Wheat System: An Environmental Perspective. In Improving the Productivity and Sustainability of Rice-Wheat Systems: Issues and Impacts; American Society of Agronomy Special Publication 65; American Society of Agronomy: Madison, WI, USA, 2015; Volume 65, pp. 27-43.

4. Jaskulska, I.; Jaskulski, D.; Różniak, M.; Radziemska, M.; Gałęzewski, L. Zonal tillage as innovative element of the technology of growing winter wheat: A field experiment under low rainfall conditions. Agriculture 2020, 10, 105. [CrossRef]

5. Radicetti, E.; Mancinelli, R.; Campiglia, E. Influence of winter cover crop residue management on weeds and yield in pepper (Capsicum annuum L.) in a Mediterranean environment. Crop. Prot. 2013, 52, 64-71. [CrossRef]

6. Jaskulska, I.; Jaskulski, D. Strip-till one-pass technology in central and eastern Europe: A MZURI pro-til hybrid machine case study. Agronomy 2020, 10, 925. [CrossRef]

7. Jaskulska, I.; Romaneckas, K.; Jaskulski, D.; Wojewódzki, P. A Strip-Till One-Pass System as a Component of Conservation Agriculture. Agronomy 2020, 10, 2015. [CrossRef]

8. Langeroodi, A.R.S.; Mancinelli, R.; Radicetti, E. How do intensification practices affect weed management and yield in Quinoa (Chenopodium quinoa willd) crop? Sustainability 2020, 12, 6103. [CrossRef]

9. Schmidt, J.H.; Bergkvist, G.; Campiglia, E.; Radicetti, E.; Wittwer, R.A.; Finckh, M.R.; Hallmann, J. Effect of tillage, subsidiary crops and fertilisation on plant-parasitic nematodes in a range of agro-environmental conditions within Europe. Ann. Appl. Biol. 2017, 171, 477-489. [CrossRef]

10. Bhandari, A.L.; Ladha, J.K.; Pathak, H.; Padre, A.T.; Dawe, D.; Gupta, R.K. Yield and Soil Nutrient Changes in a Long-Term Rice-Wheat Rotation in India. Soil Sci. Soc. Am. J. 2002, 66, 162-170. [CrossRef]

11. Bijay-Singh, Y.-S.; Ladha, J.K.; Khind, C.S.; Gupta, R.K.; Meelu, O.P.; Pasuquin, E. Long-Term Effects of Organic Inputs on Yield and Soil Fertility in the Rice-Wheat Rotation. Soil Sci. Soc. Am. J. 2004, 68, 845-853. [CrossRef]

12. Barabasz, W.; Albińska, D.; Jaśkowska, M.; Lipiec, J. Biological Effects of Mineral Nitrogen Fertilization on Soil Microorganisms. Pol. J. Environ. Stud. 2002, 11, 193-198.

13. Blackshaw, R.E. Application method of nitrogen fertilizer affects weed growth and competition with winter wheat. Weed Biol. Manag. 2004, 4, 103-113. [CrossRef]

14. Iqbal, J.; Wright, D. Effects of nitrogen supply on competition between wheat and three annual weed species. Weed Res. 1997, 37, 391-400. [CrossRef]

15. Blackshaw, R.E.; Molnar, L.J.; Janzen, H.H. Nitrogen fertilizer timing and application method affect weed growth and competition with spring wheat. Weed Sci. 2004, 52, 614-622. [CrossRef] 
16. Hlisnikovský, L.; Kunzová, E. Effect of Mineral and Organic Fertilizers on Yield and Technological Parameters of Winter Wheat (Triticum aestivum L.) on Illimerized Luvisol. Pol. J. Agron. 2014, 17, 18-24.

17. Bhattacharyya, R.; Kundu, S.; Prakash, V.; Gupta, H.S. Sustainability under combined application of mineral and organic fertilizers in a rainfed soybean-wheat system of the Indian Himalayas. Eur. J. Agron. 2008, 28, 33-46. [CrossRef]

18. Hargreaves, J.C.; Adl, M.S.; Warman, P.R. A review of the use of composted municipal soild waste in agriculture. Agric. Ecosyst. Environ. 2008, 123, 1-14. [CrossRef]

19. Chairi, F.; Aparicio, N.; Serret, M.D.; Araus, J.L. Breeding effects on the genotype $\times$ environment interaction for yield of durum wheat grown after the Green Revolution: The case of Spain. Crop. J. 2020, 8, 623-634. [CrossRef]

20. Campiglia, E.; Mancinelli, R.; De Stefanis, E.; Pucciarmati, S.; Radicetti, E. The long-term effects of conventional and organic cropping systems, tillage managements and weather conditions on yield and grain quality of durum wheat (Triticum durum Desf.) in the Mediterranean environment of Central Italy. Field Crop. Res. 2015, 176, 34-44. [CrossRef]

21. Thorsted, M.D.; Weiner, J.; Olesen, J.E. Above- and below-ground competition between intercropped winter wheat Triticum aestivum and white clover Trifolium repens. J. Appl. Ecol. 2006, 43, 237-245. [CrossRef]

22. Olsen, J.; Kristensen, L.; Weiner, J.; Griepentrog, H. Increased density and spatial uniformity increase weed suppression by spring wheat. Weed Res. 2005, 45, 316-321. [CrossRef]

23. Campiglia, E.; Radicetti, E.; Mancinelli, R. Floristic composition and species diversity of weed community after 10 years of different cropping systems and soil tillage in a Mediterranean environment. Weed Res. 2018, 58, 273-283. [CrossRef]

24. Usman, K.; Khalil, S.K.; Khan, A.Z.; Khalil, I.H.; Khan, M.A. Amanullah Tillage and herbicides impact on weed control and wheat yield under rice-wheat cropping system in Northwestern Pakistan. Soil Tillage Res. 2010, 110, 101-107. [CrossRef]

25. Ercoli, L.; Masoni, A.; Mariotti, M.; Pampana, S.; Pellegrino, E.; Arduini, I. Effect of preceding crop on the agronomic and economic performance of durum wheat in the transition from conventional to reduced tillage. Eur. J. Agron. 2017, 125-133. [CrossRef]

26. Falhi, W.; Safi, S.M.A. Effect of weed competition in the characteristics of growth and yield and its components of wheat crop Ttriticum aestioum L.: A mini review. J. Res. Ecol. 2018, 6, 1637-1646.

27. Marshall, E.J.P.; Brown, V.K.; Boatman, N.D.; Lutman, P.J.W.; Squire, G.R.; Ward, L.K. The role of weeds in supporting biological diversity within crop fields. Weed Res. 2003, 43, 77-89. [CrossRef]

28. Pollnac, F.W.; Maxwell, B.D.; Menalled, F.D. Weed community characteristics and crop performance: A neighbourhood approach. Weed Res. 2009, 49, 242-250. [CrossRef]

29. Franke, A.C.; Lotz, L.A.P.; Van Der Burg, W.J.; Van Overbeek, L. The role of arable weed seeds for agroecosystem functioning. Weed Res. 2009, 49, 131-141. [CrossRef]

30. Légère, A.; Stevenson, F.C.; Benoit, D.L. Diversity and assembly of weed communities: Contrasting responses across cropping systems. Weed Res. 2005, 45, 303-315. [CrossRef]

31. Angeloni. Available online: http:/ / www.angeloniweb.it/prodotti/lavorazioni-terreno/aratri/serie-aps/ (accessed on 29 June 2021).

32. Dondi. Available online: https://www.dondinet.it/lavorazione-terreno-a-campo-aperto/dissodatori-e-decompattatori/ dissodatori-idropneumatici/\#gref (accessed on 29 June 2021).

33. Tortella. Available online: https:/ / tortella.it/?page_id=11930 (accessed on 29 June 2021).

34. Littell, R.C.; Milliken, G.A.; Stroup, W.W.; Wolfinger, R.D. SAS System for Mixed Models; SAS Institute: Cary, NC, USA, 1996; ISBN 1555447791.

35. Gomez, K.A.; Gomez, A.A. Statistical Procedures For Agricultural Research; Indian Statistical Institute: Kolkata, India, 1984; Volume 47, pp. 296-299.

36. McCune, B.; Grace, J. MRPP (Multi-response Permutation Procedures) and related techniques. Anal. Ecol. Communities 2002, 289. [CrossRef]

37. Blossom. Available online: https://www.usgs.gov/software/blossom-statistical-package (accessed on 29 June 2021 ).

38. Zanin, G.; Otto, S.; Riello, L.; Borin, M. Ecological interpretation of weed flora dynamics under different tillage systems. Agric. Ecosyst. Environ. 1997, 66, 177-188. [CrossRef]

39. Nichols, V.; Verhulst, N.; Cox, R.; Govaerts, B. Weed dynamics and conservation agriculture principles: A review. Field Crop. Res. 2015, 183, 56-68. [CrossRef]

40. Wilson, W.L.; Abernethy, V.J.; Murphy, K.J.; Adam, A.; McCracken, D.I.; Downie, I.S.; Foster, G.N.; Furness, R.W.; Waterhouse, A.; Ribera, I. Prediction of plant diversity response to land-use change on Scottish agricultural land. Agric. Ecosyst. Environ. 2003, 94, 249-263. [CrossRef]

41. Tørresen, K.S.; Skuterud, R.; Tandsæther, H.J.; Hagemo, M.B. Long-term experiments with reduced tillage in spring cereals. I. Effects on weed flora, weed seedbank and grain yield. Crop Prot. 2003, 22, 185-200. [CrossRef]

42. Colbach, N.; Dür, C. How to model the effects of farming practices on weed emergence. Weed Res. 2005, 45, 2-17. [CrossRef]

43. Chauhan, B.S.; Singh, R.G.; Mahajan, G. Ecology and management of weeds under conservation agriculture: A review. Crop Prot. 2012, 38, 57-65. [CrossRef]

44. Pinke, G.; Pál, R.W.; Tóth, K.; Karácsony, P.; Czúcz, B.; Botta-Dukát, Z. Weed vegetation of poppy (Papaver somniferum) fields in Hungary: Effects of management and environmental factors on species composition. Weed Res. 2011, 51, 621-630. [CrossRef] 
45. Blackshaw, R.E.; Brandt, R.N.; Janzen, H.H.; Entz, T.; Grant, C.A.; Derksen, D.A. Differential response of weed species to added nitrogen. Weed Sci. 2003, 51, 532-539. [CrossRef]

46. Cathcart, R.J.; Chandler, K.; Swanton, C.J. Fertilizer nitrogen rate and the response of weeds to herbicides. Weed Sci. 2004, 52, 291-296. [CrossRef]

47. De Cauwer, B.; van den Berge, K.; Cougnon, M.; Bulcke, R.; Reheul, D. Weed seedbank responses to 12 years of applications of composts, animal slurries or mineral fertilisers. Weed Res. 2010, 50, 425-435. [CrossRef]

48. Hyvönen, T.; Ketoja, E.; Salonen, J.; Jalli, H.; Tiainen, J. Weed species diversity and community composition in organic and conventional cropping of spring cereals. Agric. Ecosyst. Environ. 2003, 97, 131-149. [CrossRef]

49. Kaur, S.; Kaur, R.; Chauhan, B.S. Understanding crop-weed-fertilizer-water interactions and their implications for weed management in agricultural systems. Crop Prot. 2018, 103, 65-72. [CrossRef]

50. Sweeney, A.E.; Renner, K.A.; Laboski, C.; Davis, A. Effect of Fertilizer Nitrogen on Weed Emergence and Growth. Weed Sci. 2008, 56, 714-721. [CrossRef]

51. Siddiqui, I.; Bajwa, R.; Huma, Z.E.; Javaid, A. Effect of six problematic weeds on growth and yield of wheat. Pak. J. Bot. 2010, 42, 2461-2471.

52. Ryan, M.R.; Smith, R.G.; Mortensen, D.A.; Teasdale, J.R.; Curran, W.S.; Seidel, R.; Shumway, D.L. Weed-crop competition relationships differ between organic and conventional cropping systems. Weed Res. 2009, 49, 572-580. [CrossRef]

53. Fried, G.; Kazakou, E.; Gaba, S. Trajectories of weed communities explained by traits associated with species' response to management practices. Agric. Ecosyst. Environ. 2012, 158, 147-155. [CrossRef]

54. Travlos, I.S.; Cheimona, N.; Roussis, I.; Bilalis, D.J. Weed-species abundance and diversity indices in relation to tillage systems and fertilization. Front. Environ. Sci. 2018, 6. [CrossRef]

55. Jaskulska, I.; Lemanowicz, J.; Breza-Boruta, B.; Siwik-Ziomek, A.; Radziemska, M.; Dariusz, J.; Białek, M. Chemical and biological properties of sandy loam soil in response to long-term organic-mineral fertilisation in a warm-summer humid continental climate. Agronomy 2020, 10, 1610. [CrossRef] 